CIRJE-F-1050

\title{
The Impacts of Emerging Asia on \\ Global Financial Markets
}

\author{
Shin-ichi Fukuda \\ The University of Tokyo \\ Mariko Tanaka \\ Musashino University \\ June 2017
}

CIRJE Discussion Papers can be downloaded without charge from:

http://www.cirje.e.u-tokyo.ac.jp/research/03research02dp.html

Discussion Papers are a series of manuscripts in their draft form. They are not intended for circulation or distribution except as indicated by the author. For that reason Discussion Papers may not be reproduced or distributed without the written consent of the author. 


\title{
The Impacts of Emerging Asia on Global Financial Markets*
}

\author{
Shin-ichi Fukuda (University of Tokyo)** \\ and \\ Mariko Tanaka (Musashino University)
}

\begin{abstract}
The purpose of this paper is to explore to what extent spillovers from Asian financial market shocks have risen during the past two decades. In the first part, we examine spillover effects in stock markets. Estimating the GVAR (Global Vector Autoregressive) model, we find that spillover effects from emerging Asia became large in the post GFC (Global Financial Crisis) period. However, we also find that most of the spillover effects were from shocks in manufacturing sector rather than from those in financial sector. This implies that the spillover effects increased in the post GFC period because of increased manufacturing sector's shocks in emerging Asia. In the second part, we examine spillover effects across different foreign exchange rates. As in the stock markets, spillover effects from emerging Asia became large in the foreign exchange markets in the post GFC period. In particular, our high frequency data analysis suggests that an exchange rate policy change by the PBC (the People's Bank of China) had positive spillover effects on the most of the advanced currencies in the post GFC period. The empirical results imply that the impact of Chinese shocks has been rising in the global financial markets.
\end{abstract}

Key words: international spillover, emerging economies, stock markets in Asia JEL classification number: F10, F32, E52

\footnotetext{
* An earlier version titled "The Impacts of Asian Financial Markets on Global Economies” was presented at the 2nd International Conference of the "Evolving Finance, Trade and Investment in Asia” in Singapore on 20-21 October 2016 and at 83rd International Atlantic Economic Conference in Berlin, Germany on 22-25 March 2017. We would like to thank Kwanho Shin, Klaas Staal, Masahiro Kawai, Ali M. Kutan, and other participants for valuable comments. This research was supported by JSPS KAKENHI Grant Number 26285044 and 15K13003 and by the Center for Advanced Research in Finance (CARF) in the University of Tokyo.

** Correspondence address: Shin-ichi FUKUDA, Faculty of Economics, University of Tokyo, 7-3-1 Hongo Bunkyo-ku Tokyo 113-0033, JAPAN. E-mail: sfukuda@e.u-tokyo.ac.jp.
} 


\section{Introduction}

Over the past two decades, the share of emerging market economies in global GDP has risen substantially. Integration of these economies into the global trading network has also progressed. Trade between advanced and emerging market economies now exceeds trade among advanced economies. As a result, macro fundamental shocks in emerging market economies came to have substantial spillover effects on advanced economies. However, despite the dramatic output and trade growth, the financial market in emerging economies has developed at a slower pace and from a lower base. As a result, many argue that financial markets in emerging economies still have a limited role in the global financial market.

The purpose of this paper is to explore to what extent spillovers from Asian financial market shocks have evolved in global financial markets during the past two decades. We particularly focus on emerging Asia and investigate what spillover effect its financial markets have had on those in advanced economies. Focusing on emerging Asian financial markets deserves to be noted for the following three reasons. First, among emerging economies, Asian economies have achieved the most remarkable economic growth called the "East Asian Miracle". The growth was temporarily slowed down after the Asian crisis in 1997-98. But in the 2000s, China has achieved miraculous economic growth and substantially increased the share of emerging Asia in global GDP. Second, despite remarkable economic growth, bond and stock markets have been less developed in these economies until recently. In the 2000s, Asian emerging economies worked on reforming their financial systems. However, despite the reforms, financial market development in the Asian economies still remained far behind those in advanced economies (see, for example, Fukuda [2013]). Third, because Asian financial markets are open only when European and US markets are closed, the use of daily data allows us to identify direction of spillover effects without simultaneous biases. If the two markets were open in the same time zone, it would be difficult to identify causality of the spillover effects. But thanks to the time difference, we can identify causality from Asian financial market shocks to Europe and the United Sates.

In the first part of this paper, we examine spillover effects across different stock markets. Estimating a GVAR (Global Vector Autoregressive) model, we find that while spillover effects from Asian stock markets to those in Europe and the United Sates had been small before the Global Financial Crisis (GFC), they became large in the post GFC period. However, we also find that most of the significant spillover effects were from shocks in the Asian manufacturing sector rather than 
those in the financial sector. This implies that spillover effects from Asian stock markets to those in Europe and the United Sates increased in the post GFC period because macro fundamental shocks in emerging Asia, especially those in China, had large impacts on advanced economies.

In the second part of this paper, we examine spillover effects across different foreign exchange rates. As in the first part, we first estimate a GVAR model and confirm that spillover effects from Asian emerging economies, especially from China, became significantly large after the GFC. Unlike in the first part, we then estimate spillovers from the Chinese Yuan (CNY) on several major currencies in a time zone during which the People's Bank of China (PBC) reports its official fixing exchange rate. We find that an exchange rate policy change by the PBC had significant spillover effects on the most of the advanced currencies in the post GFC period. ${ }^{1}$

In the literature, a numerous number of studies suggested that financial market shocks in advanced countries had large spillover effects on the rest of the world, especially on emerging market economies (EMEs) during the last decade (see, for example, Rogers et al. [2014], Gauvin, McLoughlin, and Reinhardt [2014], Neely [2015], Engel [2016], Aizenman, Chinn, and Ito [2017]). In particular, several authors found that financial market shocks in advanced countries had large spillover effects on emerging Asian economies (see, for example, Morgan [2011], Park and Um [2016], and Fukuda [2017]). However, relatively limited previous studies explored how large spillovers financial market shocks in emerging economies had on advanced economies. In particular, few investigated spillover effects from Asian financial market shocks on advanced economies. ${ }^{2}$ However, the authors such as Gelos and Surti (2016) and Huidrom, Kose, and Ohnsorge (2016) showed the growing importance of financial spillovers from emerging market economies in the 2000s, especially after the GFC. ${ }^{3}$ It is thus important to examine to what extent spillovers from Asian financial market shocks have risen in global financial markets during the past two decades.

Our empirical results suggest that the spillover effects from Asian financial market shocks increased in the post GFC period because of increased manufacturing sector's shocks in emerging Asia. The impact of shocks to economic fundamentals in emerging Asia, such as those in China, has been rising in global financial markets. It is likely that spillovers from Chinese macro fundamentals to global financial markets will increase considerably in the next few years even if Chinese financial

1 See Ito and Kawai, (2016) and Ito (2017) for recent growing role of the CNY.

2 Fujiwara and Takahashi (2012) is an exceptional study which found weak spillover effects from Asia in the pre-GFC period.

3 See also Aizenman and Fukuda (2017) and Didier, Llovet, and Schmukler (2017) both of which discuss growing role of emerging economies in the Pacific Rim. 
market remains underdeveloped.

\section{Empirical Methodology}

To investigate spillover effects from Asian stock markets to those in advanced economies, the following sections explore how stock markets in Europe and the USA reacted to those in emerging Asia. A GVAR (Global Vector Autoregressive) is estimated in order to capture financial spillovers across advanced and emerging Asian market economies. To the extent that spillovers are one-directional and have no further propagation, a single equation would be enough to capture the financial spillovers. However, shocks are propagated through a feedback loop; shocks occurred in the U.S. affect Asia, the affected Asian economy has a further impact on the U.S. economy, and the feedback loop continues for a few days. A GVAR is a useful econometric framework when such a loop exists because it can capture multilateral financial spillovers with various feedbacks across regions.

In our GVARs, endogenous variables are composed of two sets of variables. The first set of variables consists of daily stock returns from 14 countries: Japan, nine emerging Asian economies (China, Hong Kong, South Korea, Singapore, Taiwan, Thailand, Malaysia, Indonesia, and Philippines), three European countries (the UK, Germany, and France), and the USA. The main stock market index returns in local currency are used for the country-specific equity returns. ${ }^{4}$ The second set of variables consists of daily log-difference of the VIX, daily difference of 10-year US government bond yields, and daily difference of 5-year US government bond yields. They are used to account for common/systematic global factors.

As Figure 1 shows, Asian stock markets are open when European and New York markets are closed. The use of daily data thus allows us to identify spillover effects without simultaneous biases. ${ }^{5}$ Strictly speaking, the identified spillover effects do not necessarily mean causality from Asian

4 The main stock market indexes in Asia are Nikkei 225, Shanghai SSEC, Hang Seng Stock Index, Seoul Composite Index, Singapore (SES) Strait Times Index, Taiwan Weighted Price, Thailand SET-Index, Malaysia KLSE Composite Index, Indonesia Jakarta Composite Index, and Philippine Stock Exchange Index. Those in Europe and the USA are FTSE 100, DAX 30, France CAC 40, and Dow Jones Industrials.

5 To circumvent simultaneous biases, a number of previous studies used two-day average returns in literature (Forbes and Rigobon [2002]). But we did not need such transformation because simultaneous biases are less likely. Strictly speaking, the stock markets in Southeast Asia are still open when European markets start to open. However, the following results essentially hold true even if we exclude the Southeast Asian countries from our sample. 
financial shocks to European and US markets because stock prices move in anticipation of future shocks. For example, if some events are expected to happen in the USA when Asian stock markets are open, stock prices in Asia would respond earlier in anticipation of the shocks. In this case, the US stock price moves afterwards when the New York stock market opens. The timing sequence does not mean that shocks in Asia cause the changes of the US stock price. However, noting that most of the country-specific financial shocks occur when its local market is open, it is less likely that large events are expected to happen in the USA when the New York market is closed. In contrast, country-specific financial shocks in Asia usually occur before those in Europe and the USA will occur in each business day. In the following analysis, we assume that the identified spillover effects in our GVARs suggest causality from Asian financial shocks to European and US markets.

The variables within the underlying GVAR are in order of the first set and the second set. The first set is in order of Japan, nine emerging Asian economies, three European countries, and the USA. However, the order within nine emerging Asian economies and three European countries is arbitrary. In the baseline estimation, we ordered nine emerging Asian economies by China, Hong Kong, South Korea, Singapore, Taiwan, Thailand, Malaysia, Indonesia, and Philippines and three European countries by the UK, Germany, and France. But we check its robustness through changing the order of the Cholesky decomposition within nine emerging Asian economies and within three European countries respectively.

The estimation of the GVAR model is done recursively, with the number of lags set to one. ${ }^{6}$ The sample period starts in January 1992 and ends in June 2016. We split the sample into three subsample periods: January 1992 to December 1996 (i.e., pre-Asian crisis period), January 2000 to December 2006 (i.e., post-Asian crisis and pre-GFC period), and January 2010 to June 2016 (i.e., post-GFC period). The subsample periods did not include January 1997 to December 1999 and January 2007 to December 2009 to exclude the effects of the Asian crisis and the Global Financial Crisis (GFC). All data were downloaded from Datastream.

\section{Empirical results: Stock Price Spillovers}

Table 1 reports accumulated impulse responses over 10 business days after a shock. They show how many basis points the other stock price indexes will change in 10 business days when each

${ }^{6}$ Schwarz SC chose one lag in all cases, and so did AIC in most cases. Our essential results were robust even if we set the number of lags to be two. 
stock price index increases by a percent point. Since our main interest is to explore spillover effects from Asian stock markets to those in advanced economies, the table reports how the stock price responded in three European countries (i.e., the UK, Germany, and France) and in the USA when a stock price shock had occurred in each of nine emerging Asian economies (i.e., China, Hong Kong, South Korea, Singapore, Taiwan, Thailand, Malaysia, Indonesia, and Philippines). To compare them with spillover effects across the advanced countries, it also reports how the stock price responded in three European countries and in the USA when a stock market shock had occurred in each advanced country (i.e., Japan, the UK, Germany, France, and the USA).

In the first subsample period (that is, January 1992 to December 1996), the stock prices in the advanced countries, which significantly responded to shocks in the other advanced countries, rarely showed significant responses to a stock market shock in the emerging Asian economies. In particular, the stock prices in the United States showed no significant response to a stock market shock in any emerging Asian economies. In the second subsample period (that is, January 2000 to December 2006), the stock prices in the advanced countries responded not only to shocks in the other advanced countries but also to shocks in some of the emerging Asian economies. In particular, the stock prices in three European countries significantly responded to a shock in Hong Kong and Singapore. This may reflect the fact that Hong Kong and Singapore were an important financial center in Asia. However, comparing the magnitude of accumulated impulse responses, the responses to shocks in the emerging Asian economies were much smaller than the responses to shocks in the advanced countries. This implies that before the GFC, spillover effects from emerging Asian stock market shocks to the stock markets in Europe and the USA were, if any, limited.

In contrast, in the last subsample period (that is, January 2010 to June 2016), the stock prices in the advanced countries showed large responses not only to shocks in advanced countries but also to those in several emerging Asian economies. Comparing the responses in the second and last subsample periods, a shock in European countries and the USA tended to reduce their impacts in the last subsample period. A shock in Hong Kong and Singapore, on the other hand, increased their impacts substantially in the last subsample period. More interestingly, a shock in China, which had no significant impact in the second subsample, showed significant accumulated impulse responses except in Germany in the last subsample period. A shock in South Korea also had the largest accumulated impulse responses in the last subsample period except in Germany. This implies that spillover effects from emerging Asian stock market shocks became far from negligible in Europe and 
the USA in the post GFC period.

Figure 2 depicts accumulated impulse responses in the UK and the USA to a shock in Hong Kong, Singapore, China, and South Korea. It shows how each accumulated impulse response changed over 10 business days for three alternative subsample periods. Reflecting bilateral propagation within and across the regions, most of the accumulated impulse responses showed some fluctuations for the first few days throughout the subsample periods. But both in the UK and in the USA, a shock in Hong Kong and Singapore caused large accumulated impulse responses in the last subsample period which were never observed in previous two subsample periods. This implies that the two financial centers in Asia substantially increased their spillover effects in global financial markets in the post GFC period. The accumulated spillover effects from China and South Korea to the UK and the USA were much smaller than those of Hong Kong and Singapore throughout the subsample periods. But the accumulated impacts of China, which had been negligible in the first and second subsample periods, increased dramatically in the last subsample period. A shock in South Korea also increased its accumulated impacts on the UK in the last subsample period.

The results are essentially the same even if we estimated GVARs changing the order within nine emerging Asian economies and three European countries. For example, Table 2 reports accumulated impulse responses over 10 business days when we ordered nine Asian economies by South Korea, Singapore, Taiwan, China, Hong Kong, Thailand, Malaysia, Indonesia, and Philippines and three European countries by Germany, France, and the UK. The different orders changed the relative importance of several economies and countries. In particular, we observe a tendency that South Korea and Germany increased their impacts because we ordered them first in each group, while China and the UK decreased their impacts because we ordered them behind in each group. However, we still observe that spillover effects from emerging Asian shocks were, if any, limited in the first subsample period. In particular, the stock prices in the United States never showed a significant response to any shocks in the emerging Asian economies. In the second subsample period, the stock prices in the advanced countries had significant responses not only to the shocks in Hong Kong and Singapore but also to those in South Korea. However, comparing the responses, we can still observe that shocks in South Korea, Hong Kong, and Singapore had much larger impacts in the last subsample period than in the second period. In the last subsample period, the impact of a shock in South Korea, Hong Kong, and Singapore were almost equal to that in the other advanced countries had. Regardless of the order of the Cholesky decomposition, our GVARs suggest that spillover 
effects from emerging Asian shocks to stock prices in advance countries became substantial in the post GFC period.

\section{Estimation results based on industry-level stock returns}

In the last section, we found that spillover effects from stock markets in emerging Asia to those in Europe and the USA, which had been small before the GFC, became significantly large in the post GFC period. The result indicates that even in the financial markets, shocks in emerging Asia came to have much larger impacts on advanced countries after the GFC. But it does not necessarily suggest that financial linkages between emerging Asia and advanced countries were tightened after the GFC. This is because the larger impacts could have happened since real linkages such as trade linkages or FDI linkages increased between emerging Asia and advanced countries in the post-GFC period.

The purpose of this section is to explore whether the significant spillovers in the post-GFC period were originated in Asian financial sector or in Asian manufacturing sector. Specifically, using industry-level stock price data, we compare spillover effects from the manufacturing sector with those from the financial sector and investigate which sector's shocks had larger impacts on the stock markets in advanced countries. Except that we use the two industry-level stock price returns, that is, stock price returns in the manufacturing sector and those in the financial sector for emerging Asia, the estimated equations are essentially the same as those in the last two sections. However, because spillovers from Malaysia, Indonesia, and Philippines were negligible even in the post GFC-period, we dropped their stock prices from our sample and focused on the impacts of six emerging Asian economies (i.e., China, Hong Kong, South Korea, Singapore, Taiwan, and Thailand) in the analysis. When estimated a GVAR, we ordered the stock price in the manufacturing sector prior to the stock price in the financial sector in each emerging Asian economy. The countries' order is the same as that in the baseline estimation in the last section.

As in the last section, we estimate GVARs in three alternative subsample periods: January 1992 to December 1996, January 2000 to December 2006, and January 2010 to June 2016. The industry-level data were downloaded from Datastream. Table 3 reports accumulated impulse responses over 10 business days after the shock. As in Table 1, they show how many basis points the other stock price indexes will change by in 10 business days when a stock price index increases by a percent point. The table reports the stock market responses in three European countries (i.e., the UK, 
Germany, and France) and the USA to a stock market shock in each of the two sectors in six emerging Asian economies (i.e., China, Hong Kong, South Korea, Singapore, Taiwan, and Thailand). As in the last section, we find that spillover effects from an emerging Asian stock market to the stock markets in advance countries were, if any, small in the pre-GFC period but that they became large in the post GFC period. However, we see two noteworthy features which we could not see in the last section.

First, throughout the subsample periods, the stock prices in all of the advanced countries had much larger responses to a shock in the manufacturing sector than to a shock in the financial sector. Even in the first and second subsample periods, a manufacturing sector's shock in Hong Kong and Singapore had significantly positive spillover effects on the UK and Germany and so did that in Singapore on all of the advance countries. In contrast, a financial sector's shock in the emerging Asia rarely had significant spillover effects on advance countries in the first and second subsample periods. In the third subsample period, a financial sector's shock in China and Singapore had significantly positive effects on all of the advance countries. But the effects were much smaller than those of a manufacturing sector's shock. In particular, accumulated impulse responses to a Chinese manufacturing sector shock were twice as much as those to a Chinese financial sector shock in all of the advance countries. In the case of Hong Kong and South Korea, a shock had significantly positive spillover effects on the advance countries only in manufacturing sector in the third subsample period.

Second, spillover effects from a Chinese stock market shock to those in Europe and the USA became significantly large in the post GFC period. In the first and second subsample periods, a Chinese shock was significant neither in the financial sector nor in the manufacturing sector. However, in the third subsample period, a Chinese shock came to have significantly large impacts not only in the manufacturing sector but also in the financial sector, although shocks in the manufacturing sector had much larger spillovers than those in the financial sector. Accumulated impulse responses to a Chinese manufacturing sector shock in the third subsample period were more than 10 times larger than those in the second subsample period in the UK and France, and were more than 7 times larger than those in the second subsample period in Germany and the USA.

These features suggest that spillover effects from emerging Asian stock markets to those in Europe and the United Sates increased in the post GFC period mainly because manufacturing sector's shocks in emerging Asia, especially shocks in the China's manufacturing sector, had large 
impacts on macro fundamentals in advanced economies. Direct financial linkages between emerging Asia and advanced countries were, if any, small even after the GFC. This was true for Hong Kong and Singapore which are important financial center in Asia.

Strictly speaking, the identified spillover effects do not necessarily mean causality from Asian manufacturing sector's shocks to European and US markets. For example, suppose that there is a news shock in the USA that will decrease its demand for manufacturing goods from emerging Asia. Since stock prices move in anticipation of future shocks, the stock price of the manufacturing sector in emerging Asia would decline first if a news shock occurs when Asian markets are open. But in this case, the root of the shock lies in the USA not in emerging Asia. Our analysis implicitly rules out such a possibility assuming that country-specific manufacturing sector's shocks occur when its local market is open.

It is noteworthy that the share of emerging Asia in the global trading network has progressed steadily over the last decade. For example, Figure 3 depicts how the share of emerging Asia, especially that of China, changed in the imports of the USA and Europe from 1980 to 2015. It shows that the share of emerging Asia, especially that of China, has increased steadily in the 2000s. ${ }^{7}$ However, because the financial market in emerging Asia had developed at a slower pace, the increased real linkage had little impact on financial linkage until the post GFC-period. This implies that real linkage between emerging Asia and advanced economies had no significant impact on financial linkage between the two regions unless it had reached some threshold level. Only when it reached a threshold level, the increased real linkage has tightened financial linkage significantly. In particular, reflecting increased role of China in global economy, Chinese shocks came to have large impacts on advance countries even in financial sector in the post GFC period.

\section{Exchange Rate Spillovers}

In previous sections, we explored spillover effects from Asian stock markets to those in Europe and the United Sates. In the following sections, we will examine spillover effects across different foreign exchange rates. As in the previous sections, we first estimate a GVAR model and investigate how exchange rates in Europe and the USA reacted to those in emerging Asia. In the GVAR, the endogenous variables are composed of two sets of variables. The first set of variables consists of

7 See also Helble and Ngiang (2016). 
daily log-differenced exchange rates from 13 currencies: the Japanese Yen, nine emerging Asian currencies (the Chinese Yuan (CNY), the Hong Kong Dollar, the Korean Won, the Singapore Dollar, the New Taiwan Dollar, the Thai Baht, the Malaysian Ringgit, the Indonesian Rupiah, and the Philippine Peso), two European currencies (the UK Pound and the Euro), and the US Dollar. ${ }^{8}$ In the benchmark case, we denominate all of the currencies in the Swiss Franc. ${ }^{9}$ The second set of variables consists of daily log-differenced VIX, daily differenced 10-year US government bond yields, and daily differenced 5-year US government bond yields. As in the last sections, they are used to account for common/systematic global factors.

Since most of the Asian emerging economies adopted de facto fixed exchange rate regime before the Asian crisis, we estimate the GVAR only for the latter two subsample periods: January 2000 to December 2006 (i.e., post-Asian crisis and pre-GFC period) and January 2010 to June 2016 (i.e., post-GFC period). The subsample periods did not include January 2007 to December 2009 to exclude the effects of the GFC. All of the exchange rates were downloaded from Datastream.

The estimation of the GVAR model is done recursively, with the number of lags set to one. ${ }^{10}$ Table 4 reports accumulated impulse responses over 10 business days after the shock. They show basis points by which the other exchange rates will depreciate in 10 business days when an exchange rate depreciates by a percent point. Since our main interest is to explore spillover effects from Asian markets to those in advanced economies, the table reports the exchange rate responses of two European currencies and the US Dollar to the exchange rate shock in each of nine emerging Asian currencies. For comparison, it also reports the exchange rate market responses of the three currencies to the exchange rate shock in each currency of the advanced countries. As in the stock markets, the table shows that exchange rate spillover effects from Asian emerging economies became significantly large after the GFC.

Even in the subsample period from January 2000 to December 2006, the exchange rates in the advanced countries responded to an exchange rate shock in some emerging Asian economies. In particular, all of the advanced currencies had significant responses to a shock in the CNY. However, before the GFC, spillover effects from Asian exchange rate shocks to the exchange rates in advance

\footnotetext{
8 Before the launch of the Euro, we used the German Mark instead of the Euro.

9 We checked robustness denominating all of the currencies in the Australian dollar. The results were essentially the same.

10 Schwarz SC chose one lag in all cases, and so did AIC in most cases. The results did not change even if we set the number of lags to be two.
} 
countries were, if any, small. In contrast, in the subsample period from January 2010 to June 2016, the exchange rates in the advanced countries had significant responses to the exchange rate shock in China, Hong Kong, South Korea, and Singapore. In particular, a shock in the Chinese currency increased its spillover effects dramatically in the post GFC period. This implies that after the GFC, Asian exchange rate shocks, especially Chinese exchange rate shocks, came to have large spillover effects on the exchange rates in advance countries. The result supports our view that reflecting increased role of China in global economy, Chinese currency shocks came to have large impacts on advance countries even in the foreign exchange markets in the post GFC period.

\section{Hourly Spillover Effects from the RMB}

In the last section, we found that spillover effects from Asian exchange rate shocks, especially from a China's exchange rate shock, became large in the global economy in the post-GFC period. However, the foreign exchange markets for major currencies are open for 24 hours a day. In addition, the exchange rates are susceptible to currency-specific shocks of the numeraire currency. Thus, unlike in the stock markets, the time difference in daily data does not necessarily allow us to identify the direction of the spillover effects. When we cannot identify the direction, we need to interpret the results with reservations. The purpose of this section is to investigate whether the results in the last section are still robust even if we identify the direction of the spillover effects by using high frequency data. The method of estimation follows Frankel and Wei (1994). Using the Swiss Franc as a benchmark currency, we estimate the following equation by using log difference of hourly data of the exchange rates. ${ }^{11}$

(1) $\Delta \ln \left(\mathrm{z}_{\mathrm{t}}^{\mathrm{A}}\right)=$ constant $+a_{1} \Delta \ln \left(C N Y_{\mathrm{t}}\right)+a_{2} \Delta \ln \left(\mathrm{Yen}_{\mathrm{t}}\right)+a_{3} \Delta \ln \left(\mathrm{z}_{\mathrm{t}}^{\mathrm{B}}\right)+a_{4} \Delta \ln \left(\mathrm{z}_{\mathrm{t}}^{\mathrm{C}}\right)$,

where $z^{A}$ is the exchange rate in advanced country $A$ and $z^{B}{ }_{t}$ and $z^{C}$ are those in the other advanced country.

One possible problem with estimating equation (1) is that it may suffer from simultaneous biases and multicollinearity (see, for example, Fukuda and Ohno [2008] and Kawai and Pontines [2016]). To avoid the problem, we use hourly changes in the exchange rates from GMT (Greenwich Mean

11 The results were essentially the same even if we changed the numeraire currency from the Swiss franc to the US dollar. 
Time) 1AM to 2AM and examine what spillovers we can observe from the Chinese Yuan (CNY) to several major currencies. Hourly data from GMT 1AM to 2AM, which is from 9AM to 10AM in China time, is useful for avoiding simultaneous biases in the following three respects.

First, the CNY's changes from GMT 1AM to 2AM are likely to reveal exchange rate policy changes by the People's Bank of China (PBC). The PBC reports its official fixing exchange rate, that is, the central parity of CNY at 9:15 AM in China time every business day. Even though the PBC recently made the exchange rate system more market based, the CNY's central rate has still been set at the discretion of the authorities, especially before August 11, 2015 when the central rate was set based on the exchange rate in the onshore market at the close of the previous day. It is thus likely that exogenous policy changes by the PBC are reflected in the CNY's changes from GMT 1AM to 2AM during which the PBC reports the central parity of the CNY.

Second, GMT 1AM to 2AM is one of the time zones when the CNY actually changed most in the post GFC period. Reflecting the fact that the CNY was effectively controlled by the PBC, changes in the CNY were highly heterogeneous across different time zones. In particular, the CNY showed substantial changes against the US Dollar only in specific time zones in a day. Figure 4 depicts the standard deviation and the maximum of hourly changes of the CNY denominated in the US Dollar from 7 April 2010 to 31 August 2016. It indicates that the CNY changed little against the US Dollar except for the time zones from GMT 1AM to 2AM and from GMT 23PM to 24PM. In other words, most of the daily changes in the CNY were attributable to hourly changes from GMT 1AM to $2 \mathrm{AM}^{12}$

Third, GMT 1AM to 2AM corresponds to the time zone from 2AM to 3AM (or from 3PM to 4AM in summer) in London time and from 9PM to 10PM (or from 10PM to 11PM in summer) in New York time. Noting that large local shocks are less likely to happen in night time, this implies that most of the large exogenous shocks which affect the exchange rates are likely to be originated in East Asia in the time zone from GMT 1AM to 2AM. Thus restricting our exchange rates to those from GMT 1AM to 2AM, it would be easier to identify direction of exchange rate spillover effects from China to Europe and the USA.

For dependent variables, we use five alternative advanced currencies: the US Dollar, the UK Pound, the Euro, the Norway Krone, and the Canadian Dollar. In the benchmark case, all of them are

12 Changes from GMT 23PM to 24PM also contributed to the daily changes in the CNY. But unlike changes from GMT 1AM to 2AM, changes from GMT 23PM to 24PM were large because of infrequent large shocks. 
denominated in the Swiss Franc. The sample period is from 7 April 2010 to 31 August 2016. All of the hourly data were downloaded from Datastream. Table 5 summarizes the estimation results. It reports the estimation results with and without the lag dependent variable. Among the advanced currencies, the CNY had the largest effect on the US Dollar; 1\% appreciation of the CNY caused about $0.27 \%$ appreciation of the US Dollar. This may reflect the fact that the US Dollar is dominant international currency in Asia. But the CNY also had significantly positive effect on the other advanced currencies except the Euro; $1 \%$ appreciation of the CNY caused about $0.05 \%$ appreciation of the UK Pound and about $0.06 \%$ appreciation of the Canadian Dollar. This was true even if we allow the effects of the other major currencies and of the lag dependent variable. This implies that an exchange rate policy change by the PBC had spillover effects on most of the major currencies in the world in the post GFC period.

\section{Concluding Remarks}

In this paper, we explored to what extent spillovers from Asian financial market shocks have risen during the past two decades. In both stock and foreign exchange markets, we found that spillover effects from emerging Asia became much larger in the post GFC period. However, we also found that the spillover effects in the stock markets were mostly from shocks in the manufacturing sector rather than from those in the financial sector. In particular, a rise of China contributed a lot in increasing the spillover effects from emerging Asia. This implies that the spillover effects increased in the post GFC period because of increased manufacturing sector's shocks in emerging Asia, especially in China.

Over the past two decades, the role of Asian emerging market economies, especially China, has risen substantially in global economy. As a result, macro fundamental shocks in emerging market economies came to have substantial spillover effects on advanced economies. Our empirical results support the view that even though the financial market in emerging Asia has developed at a slower pace, the impact of emerging Asia, especially China, has been rising in the global financial markets. 


\section{References}

Aizenman, J., M. D. Chinn, and H. Ito, (2017), "Balance Sheet Effects on Monetary and Financial Spillovers: The East Asian Crisis Plus 20,” Journal of International Money and Finance, 74, 258-282.

Aizenman, J., and S. Fukuda, (2017), “The Pacific Rim and the Global Economy: Future Financial and Macro Challenges,” Journal of International Money and Finance, 74, 229-231.

Didier, T., R. Llovet, and S. L. Schmukler, (2017), “International Financial Integration of East Asia and Pacific,” Journal of the Japanese and International Economies, 44, 52-56.

Engel, C., (2016), "Macroprudential Policy under High Capital Mobility: Policy Implications from an Academic Perspective,” Journal of the Japanese and International Economies, 42, 162-172.

Forbes, K.J., and R. Rigobon. (2002), “No Contagion, Only Interdependence: Measuring Stock Market Co-Movements,” Journal of Finance 57(5), 2223-261.

Frankel, J., and S.-J. Wei, (1994), "Yen bloc or dollar bloc? Exchange rate policies of the East Asian economies,” in T. Ito, A. Krueger (Eds.), Macroeconomic Linkages: Savings, Exchange Rates and Capital Flows, University of Chicago Press, Chicago.

Fujiwara, I., and K. Takahashi, (2012), “Asian Financial Linkage: Macro-finance Dissonance,” Pacific Economic Review 17(1), 136-159.

Fukuda, S., and S. Ohno, (2008), "Post-crisis Exchange Rate Regimes in ASEAN: A New Empirical Test Based on Intra-daily Data” Singapore Economic Review, 53(2), 191 - 213.

Fukuda, S., (2013), "Finance,” in H. Hill and M.S.G. Bautista eds, Asia Rising: Growth and Resilience in an Uncertain Global Economy, Chapter 6, Edward Elgar, 154-183.

Fukuda, S., (2017), “Spillover Effects of Japan’s Quantitative and Qualitative Easing on East Asian Economies,” ADBI Working Paper Series No.631.

Gauvin, L., C McLoughlin, and D Reinhardt (2014), "Policy Uncertainty Spillovers to Emerging Markets: Evidence from Capital Flows”, Bank of England Working Paper 512.

Gelos, G., and J. Surti, (2016), “The Growing Importance of Financial Spillovers from Emerging Market Economies,” IMF Global Stability Report (Chapter 2), 1-30.

Helble, M., and B.-L. Ngiang, (2016), “From Global Factory to Global Mall? East Asia’s Changing Trade Composition and Orientation,” Japan and the World Economy, 39, 37-47.

Huidrom, R., M.A. Kose, and F. Ohnsorge, (2016), “A Ride in Rough Waters,” IMF Finance \& 
Development, 53(3), 34-37.

Ito, H., and M. Kawai, (2016), “Trade Invoicing in Major Currencies in the 1970s-1990s: Lessons for Renminbi Internationalization,” Journal of the Japanese and International Economies, 42, 123-145.

Ito, T., (2017), “A New Financial Order in Asia: Will a RMB Bloc Emerge?” Journal of International Money and Finance, 74, 232-257.

Kawai, M., and V. Pontines, (2016). "Is There Really a Renminbi Bloc in Asia?: Modified Frankel-Wei Approach,” Journal of International Money and Finance 62, 72-97.

Morgan, P. J., (2011), “Impact of US Quantitative Easing Policy on Emerging Asia,” ADBI Working Paper Series No.321.

Neely, C. J., (2015), “Unconventional Monetary Policy had Large International Effects,” Journal of Banking \& Finance 52, 101-11.

Park, K.Y., and J.Y. Um, (2016), "Spillover Effects of U.S. Unconventional Monetary Policy on Korean Bond Markets: Evidence from High-Frequency Data," The Developing Economies 54(1), 27-58.

Rogers, J.H., C. Scotti, and J.H. Wright, (2014), "Evaluating Asset-Market Effects of Unconventional Monetary Policy: A Cross-Country Comparison,” International Finance Discussion Papers 1101, Board of Governors of the Federal Reserve System (U.S.). 
Figure 1. The Time Zones for which Each Stock Market is Open

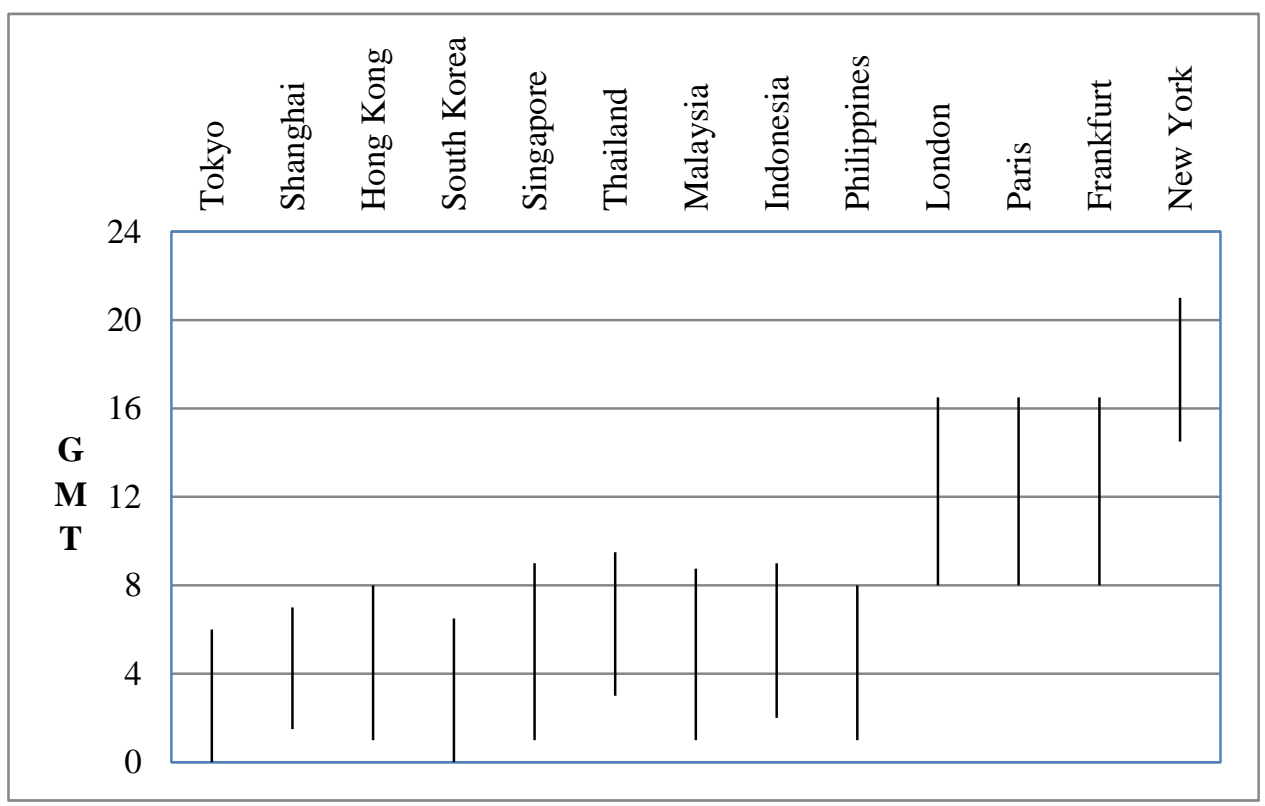

Note) The time zone is based on winter time. Asian financial markets are open when European and New York markets are closed and European and New York markets are open when Asian financial markets are closed. 
Figure 2. Accumulated Impulse Responses in the UK and the USA

(1) The UK
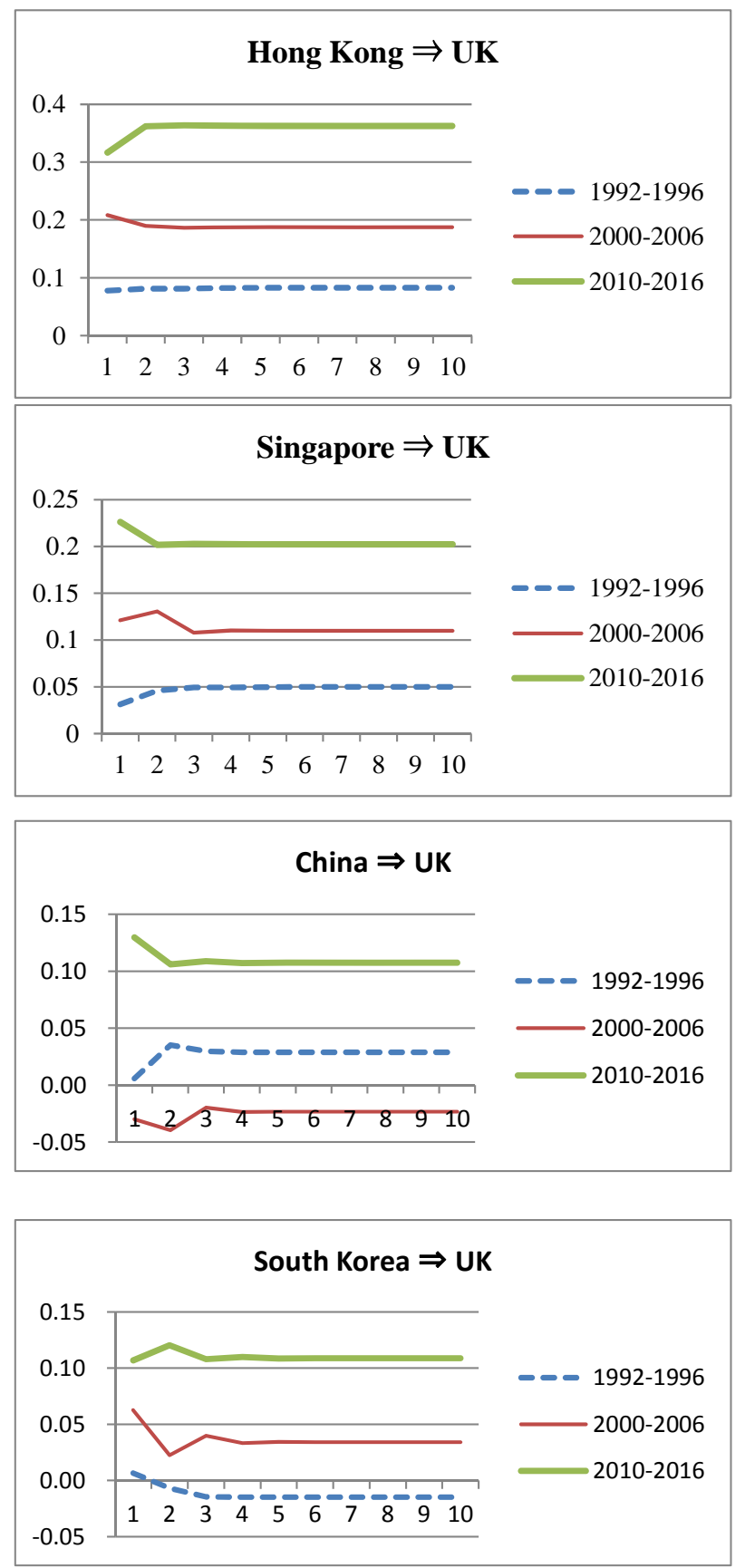
Figure 2. Accumulated Impulse Responses in the UK and the USA (continued)

(2) The USA
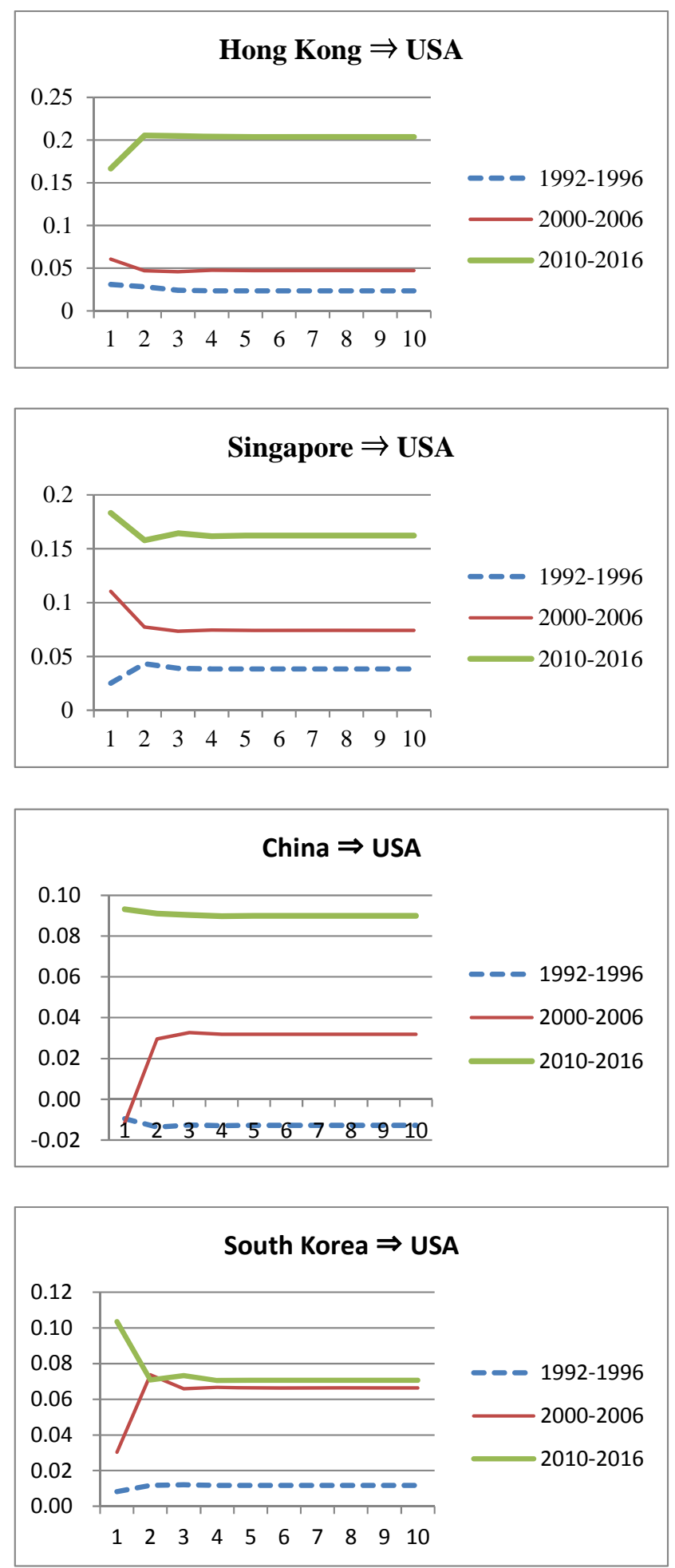
Figure 3. The Share of Emerging Asia in the Imports of the USA and Europe
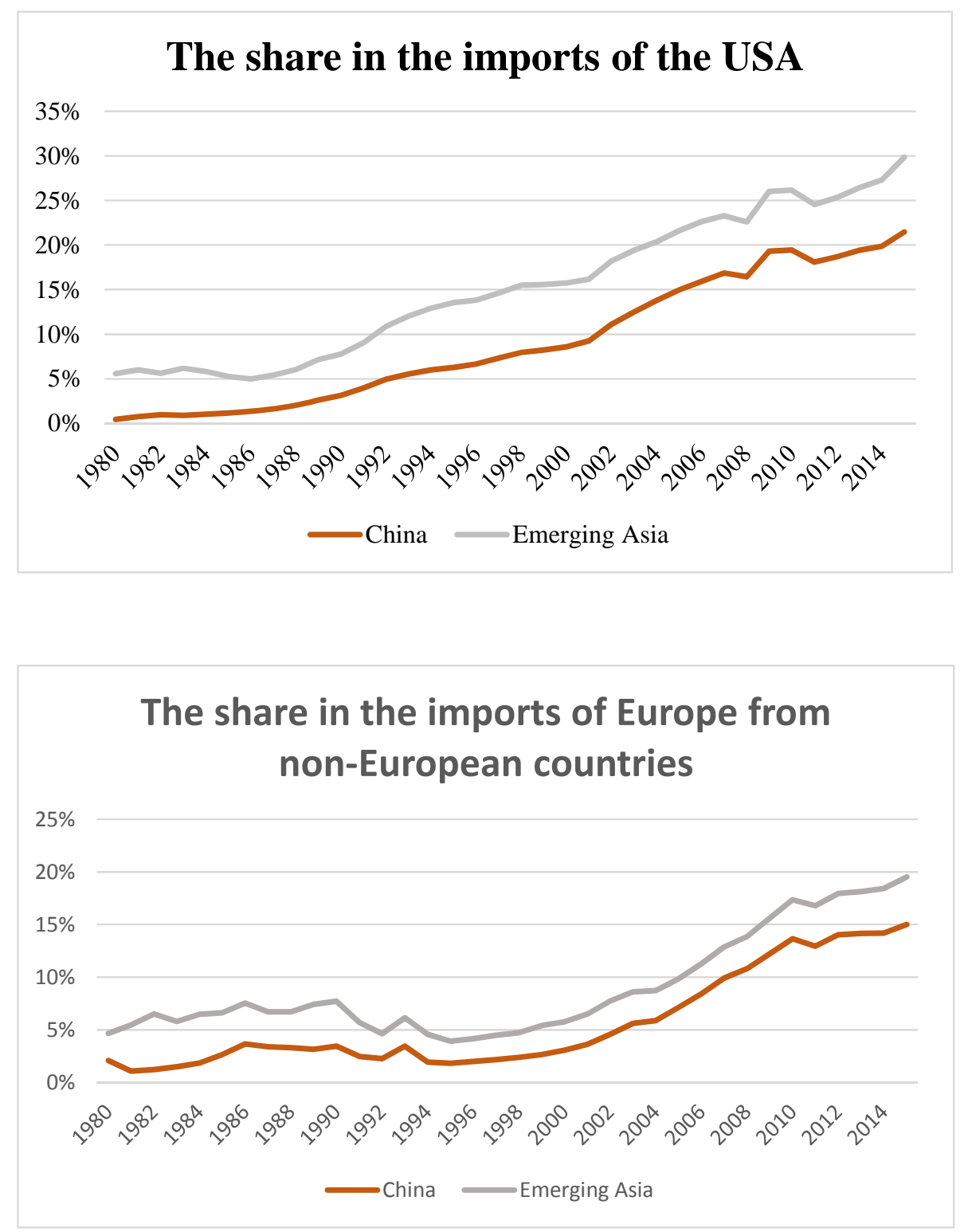
Figure 4. Standard Deviation and Maximum of Hourly Changes of the CNY
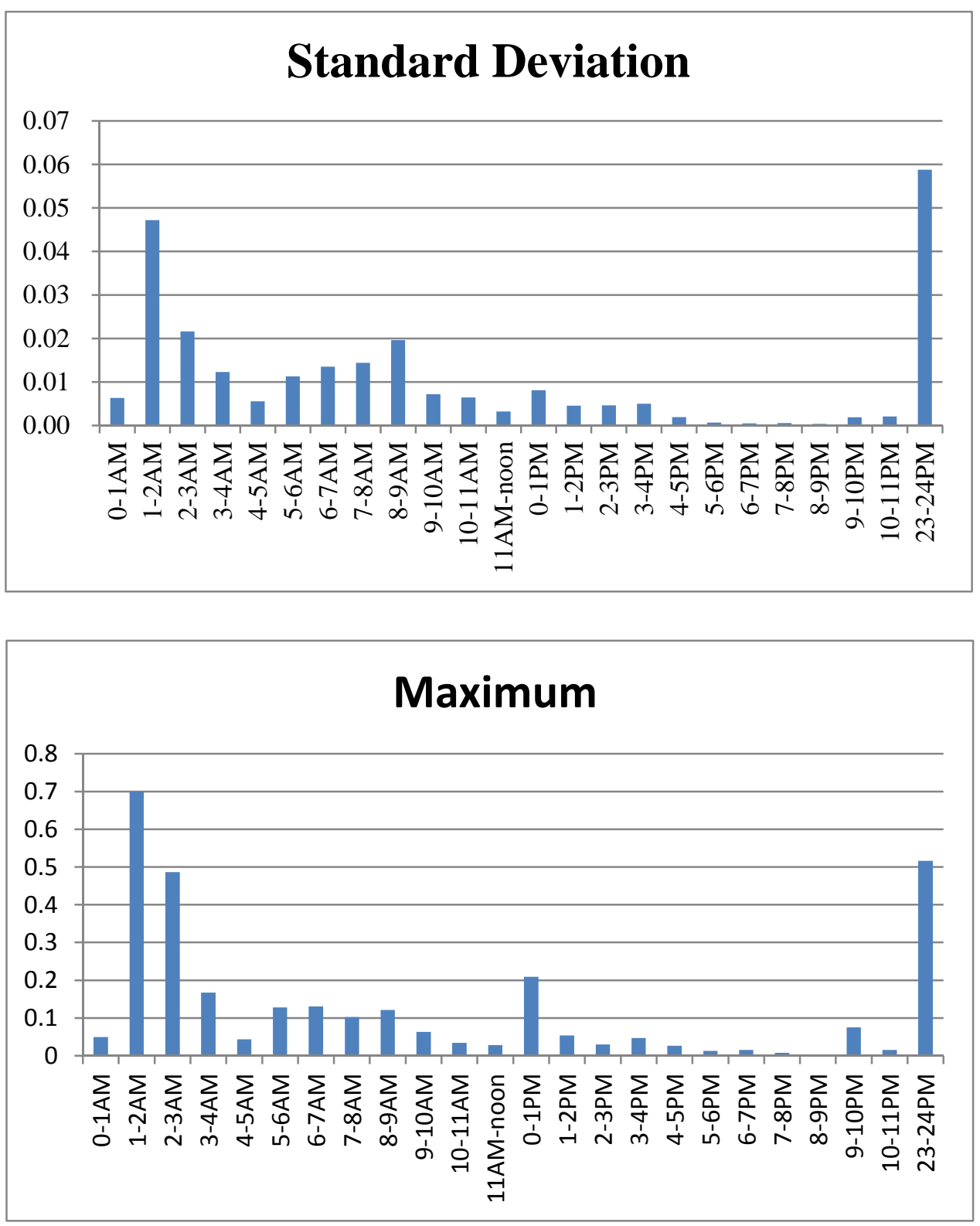
Table 1. Accumulated Impulse Responses in the Stock Markets

\begin{tabular}{|c|c|c|c|c|c|c|c|c|c|c|c|c|}
\hline & (1) UK & & & & & & (2) Germar & & & & & \\
\hline & $1992-1996$ & & $2000-2000$ & & $2010-2016$ & & $1992-199$ & & $2000-200$ & & $2010-201$ & \\
\hline China & 0.0288 & & -0.0233 & & 0.1073 & & 0.0569 & & -0.0102 & & 0.0773 & \\
\hline & $(0.031)$ & & $(0.036)$ & & $(0.036)$ & $*$ & $(0.035)$ & & $(0.052)$ & & $(0.047)$ & \\
\hline Hong Kong & 0.0828 & & 0.1874 & & 0.3627 & & 0.1156 & & 0.3121 & & 0.4285 & \\
\hline & $(0.030)$ & $*$ & $(0.034)$ & ** & $(0.035)$ & ** & $(0.034)$ & $* *$ & $(0.049)$ & ** & $(0.046)$ & ** \\
\hline Korea & -0.0147 & & 0.0340 & & 0.1086 & & 0.0111 & & 0.1010 & & 0.0805 & \\
\hline & $(0.030)$ & & $(0.034)$ & & $(0.033)$ & $*$ & $(0.034)$ & & $(0.049)$ & $*$ & $(0.044)$ & \\
\hline Singapore & 0.0500 & & 0.1099 & & 0.2023 & & 0.0526 & & 0.1524 & & 0.2534 & \\
\hline & $(0.031)$ & & $(0.034)$ & ** & $(0.032)$ & ** & $(0.035)$ & & $(0.050)$ & ** & $(0.043)$ & $* *$ \\
\hline Taiwan & -0.0357 & & 0.0165 & & 0.0426 & & 0.0766 & & 0.1139 & & 0.0483 & \\
\hline & $(0.029)$ & & $(0.034)$ & & $(0.033)$ & & $(0.033)$ & $*$ & $(0.049)$ & $*$ & $(0.044)$ & \\
\hline Thailand & 0.0279 & & -0.0151 & & 0.0131 & & 0.0262 & & 0.0211 & & 0.0484 & \\
\hline & $(0.031)$ & & $(0.034)$ & & $(0.033)$ & & $(0.034)$ & & $(0.049)$ & & $(0.044)$ & \\
\hline Malaysia & 0.0529 & & -0.1764 & & -0.0150 & & -0.0271 & & -0.1717 & & -0.0371 & \\
\hline & $(0.031)$ & & $(0.038)$ & ** & $(0.035)$ & & $(0.035)$ & & $(0.055)$ & & $(0.047)$ & \\
\hline Indonesia & 0.0630 & & -0.0583 & & 0.0244 & & 0.0087 & & -0.0822 & & 0.0385 & \\
\hline & $(0.034)$ & & $(0.036)$ & & $(0.034)$ & & $(0.038)$ & & $(0.052)$ & & $(0.045)$ & \\
\hline Phillipines & -0.0131 & & -0.0008 & & -0.0616 & & 0.0179 & & -0.0500 & & -0.1160 & \\
\hline & $(0.032)$ & & $(0.036)$ & & $(0.033)$ & & $(0.035)$ & & $(0.052)$ & & $(0.044)$ & $* *$ \\
\hline Japan & 0.0882 & & 0.1576 & & 0.2496 & & 0.0984 & & 0.2821 & & 0.3296 & \\
\hline & $(0.03)$ & $*$ & $(0.034)$ & ** & $(0.034)$ & $* *$ & $(0.034)$ & $*$ & $(0.049)$ & $* *$ & $(0.044)$ & $* *$ \\
\hline UK & 0.7380 & & 0.9707 & & 0.8949 & & 0.4449 & & 1.0274 & & 0.9771 & \\
\hline & $(0.027)$ & ** & $(0.028)$ & ** & $(0.029)$ & $* *$ & $(0.033)$ & $* *$ & $(0.044)$ & ** & $(0.040)$ & ** \\
\hline Germany & -0.0353 & & 0.0976 & & -0.0009 & & 0.6373 & & 0.9990 & & 0.7123 & \\
\hline & $(0.019)$ & & $(0.023)$ & $* *$ & $(0.028)$ & & $(0.026)$ & ** & $(0.037)$ & ** & $(0.038)$ & $* *$ \\
\hline France & -0.0307 & & -0.0474 & & -0.0263 & & 0.1630 & & -0.0432 & & -0.0623 & \\
\hline & $(0.022)$ & & $(0.022)$ & * & $(0.026)$ & & $(0.026)$ & ** & $(0.032)$ & & $(0.034)$ & \\
\hline US & 0.1310 & & 0.2380 & & 0.1770 & & 0.2659 & & 0.2284 & & 0.1851 & \\
\hline & $(0.022)$ & ** & $(0.023)$ & ** & $(0.021)$ & ** & $(0.025)$ & $* *$ & $(0.033)$ & ** & $(0.028)$ & $* *$ \\
\hline
\end{tabular}


Table 1. Accumulated Impulse Responses in the Stock Markets (continued)

\begin{tabular}{|c|c|c|c|c|c|c|c|c|c|c|c|c|}
\hline & (3) France & & & & & & (4) US & & & & & \\
\hline & 1992-1996 & & $2000-2000$ & & $2010-2016$ & & 1992-1996 & & $2000-200$ & & $2010-2016$ & \\
\hline \multirow[t]{2}{*}{ China } & 0.0783 & & -0.0449 & & 0.1118 & & -0.0128 & & 0.0318 & & 0.0899 & \\
\hline & $(0.042)$ & & $(0.046)$ & & $(0.047)$ & * & $(0.026)$ & & $(0.035)$ & & $(0.031)$ & * \\
\hline \multirow[t]{2}{*}{ Hong Kong } & 0.1076 & & 0.2608 & & 0.4413 & & 0.0236 & & 0.0474 & & 0.2036 & \\
\hline & $(0.041)$ & * & $(0.044)$ & ** & $(0.046)$ & $* *$ & $(0.026)$ & & $(0.034)$ & & $(0.030)$ & $* *$ \\
\hline \multirow[t]{2}{*}{ Korea } & -0.0056 & & 0.0763 & & 0.0825 & & 0.0117 & & 0.0664 & & 0.0706 & \\
\hline & $(0.041)$ & & $(0.044)$ & & $(0.044)$ & & $(0.026)$ & & $(0.034)$ & & $(0.029)$ & * \\
\hline \multirow[t]{2}{*}{ Singapore } & 0.0458 & & 0.1583 & & 0.2698 & & 0.0385 & & 0.0742 & & 0.1621 & \\
\hline & $(0.042)$ & & $(0.045)$ & ** & $(0.043)$ & $* *$ & $(0.026)$ & & $(0.034)$ & $*$ & $(0.028)$ & $* *$ \\
\hline \multirow[t]{2}{*}{ Taiwan } & 0.0164 & & 0.0616 & & 0.0341 & & -0.0310 & & 0.0709 & & 0.0469 & \\
\hline & $(0.040)$ & & $(0.044)$ & & $(0.044)$ & & $(0.025)$ & & $(0.034)$ & $*$ & $(0.029)$ & \\
\hline \multirow[t]{2}{*}{ Thailand } & -0.0268 & & 0.0432 & & 0.0234 & & -0.0205 & & -0.0212 & & -0.0065 & \\
\hline & $(0.042)$ & & $(0.044)$ & & $(0.044)$ & & $(0.026)$ & & $(0.034)$ & & $(0.029)$ & \\
\hline \multirow[t]{2}{*}{ Malaysia } & -0.0198 & & -0.2011 & & -0.0175 & & 0.0074 & & -0.1185 & & -0.0376 & \\
\hline & $(0.042)$ & & $(0.050)$ & ** & $(0.046)$ & & $(0.026)$ & & $(0.038)$ & $*$ & $(0.031)$ & \\
\hline \multirow[t]{2}{*}{ Indonesia } & 0.0363 & & -0.0895 & & 0.0431 & & 0.0199 & & -0.0596 & & 0.0239 & \\
\hline & $(0.046)$ & & $(0.047)$ & & $(0.045)$ & & $(0.029)$ & & $(0.036)$ & & $(0.030)$ & \\
\hline \multirow[t]{2}{*}{ Phillipines } & -0.0015 & & -0.0375 & & -0.1224 & & -0.0010 & & 0.0089 & & -0.0436 & \\
\hline & $(0.043)$ & & $(0.046)$ & & $(0.044)$ & $*$ & $(0.027)$ & & $(0.036)$ & & $(0.029)$ & \\
\hline \multirow[t]{2}{*}{ Japan } & 0.1472 & & 0.2368 & & 0.3397 & & 0.0525 & & 0.1044 & & 0.1945 & \\
\hline & $(0.041)$ & ** & $(0.044)$ & ** & $(0.044)$ & $* *$ & $(0.025)$ & * & $(0.033)$ & * & $(0.029)$ & $* *$ \\
\hline \multirow[t]{2}{*}{ UK } & 0.5938 & & 1.0397 & & 1.0404 & & 0.1874 & & 0.4541 & & 0.5579 & \\
\hline & $(0.039)$ & $* *$ & $(0.039)$ & ** & $(0.040)$ & $* *$ & $(0.025)$ & $* *$ & $(0.032)$ & $* *$ & $(0.027)$ & ** \\
\hline \multirow[t]{2}{*}{ Germany } & 0.2218 & & 0.5744 & & 0.4668 & & -0.0016 & & 0.3893 & & 0.1588 & \\
\hline & $(0.034)$ & ** & $(0.033)$ & $* *$ & $(0.038)$ & $* *$ & $(0.023)$ & & $(0.030)$ & $* *$ & $(0.027)$ & $* *$ \\
\hline \multirow[t]{2}{*}{ France } & 0.7807 & & 0.4475 & & 0.3750 & & 0.0962 & & -0.0550 & & 0.0246 & \\
\hline & $(0.034)$ & ** & $(0.030)$ & $* *$ & $(0.035)$ & ** & $(0.025)$ & $* *$ & $(0.029)$ & & $(0.026)$ & \\
\hline \multirow[t]{2}{*}{ US } & 0.1903 & & 0.2676 & & 0.1943 & & 0.6075 & & 0.8287 & & 0.5828 & \\
\hline & $(0.030)$ & $* *$ & $(0.030)$ & $* *$ & $(0.028)$ & $* *$ & $(0.022)$ & $* *$ & $(0.026)$ & $* *$ & $(0.021)$ & $* *$ \\
\hline
\end{tabular}

Note 1) Table reports accumulated impulse responses over 10 business days after a shock.

2) Standard error is in the parenthesis.

$3)^{*}$ means that $\pm 2 \sigma$ is different from zero. ** means that $\pm 3 \sigma$ is different from zero. 
Table 2. Accumulated Impulse Responses in Alternative Orders

\begin{tabular}{|c|c|c|c|c|c|c|c|c|c|c|c|c|}
\hline & (1) UK & & & & & & (2) Germany & & & & & \\
\hline & 1992-1996 & & $2000-2006$ & & $2010-2016$ & & 1992-1996 & & $2000-2006$ & & $2010-2016$ & \\
\hline \multirow[t]{2}{*}{ China } & 0.0262 & & -0.0299 & & -0.00149 & & 0.0546 & & -0.0197 & & -0.0455 & \\
\hline & $(0.031)$ & & $(0.035)$ & & $(0.035)$ & & $(0.035)$ & & $(0.051)$ & & $(0.047)$ & \\
\hline \multirow{2}{*}{ Hong Kong } & 0.0628 & & 0.105 & & 0.1621 & & 0.0844 & & 0.1655 & & 0.2029 & \\
\hline & $(0.030)$ & * & $(0.034)$ & * & $(0.032)$ & ** & $(0.033)$ & * & $(0.050)$ & ** & $(0.043)$ & ** \\
\hline \multirow[t]{2}{*}{ Korea } & -0.0138 & & 0.1042 & & 0.2631 & & 0.0117 & & 0.2144 & & 0.2591 & \\
\hline & $(0.030)$ & & $(0.034)$ & * & $(0.035)$ & ** & $(0.034)$ & & $(0.050)$ & ** & $(0.046)$ & $* *$ \\
\hline \multirow[t]{2}{*}{ Singapore } & 0.0766 & & 0.161 & & 0.3133 & & 0.091 & & 0.2344 & & 0.3841 & \\
\hline & $(0.032)$ & * & $(0.034)$ & ** & $(0.033)$ & ** & $(0.035)$ & * & $(0.050)$ & ** & $(0.044)$ & ** \\
\hline \multirow[t]{2}{*}{ Taiwan } & -0.0315 & & 0.0226 & & 0.0629 & & 0.0825 & & 0.1236 & & 0.0688 & \\
\hline & $(0.030)$ & & $(0.034)$ & & $(0.033)$ & & $(0.033)$ & * & $(0.049)$ & $*$ & $(0.044)$ & \\
\hline \multirow[t]{2}{*}{ Thailand } & 0.0279 & & -0.0151 & & 0.0131 & & 0.0262 & & 0.0211 & & 0.0484 & \\
\hline & $(0.031)$ & & $(0.034)$ & & $(0.033)$ & & $(0.034)$ & & $(0.049)$ & & $(0.044)$ & \\
\hline \multirow[t]{2}{*}{ Malaysia } & 0.0529 & & -0.1764 & & -0.015 & & -0.0271 & & -0.1717 & & -0.0371 & \\
\hline & $(0.031)$ & & $(0.038)$ & $* *$ & $(0.035)$ & & $(0.035)$ & & $(0.055)$ & ** & $(0.047)$ & \\
\hline \multirow[t]{2}{*}{ Indonesia } & 0.063 & & -0.0583 & & 0.0244 & & 0.00866 & & -0.0822 & & 0.0385 & \\
\hline & $(0.034)$ & & $(0.036)$ & & $(0.034)$ & & $(0.038)$ & & $(0.052)$ & & $(0.045)$ & \\
\hline \multirow[t]{2}{*}{ Phillipines } & -0.0131 & & -0.000832 & & -0.0616 & & 0.0179 & & -0.05 & & -0.116 & \\
\hline & $(0.032)$ & & $(0.036)$ & & $(0.033)$ & & $(0.035)$ & & $(0.052)$ & & $(0.044)$ & * \\
\hline \multirow[t]{2}{*}{ Japan } & 0.0882 & & 0.1576 & & 0.2496 & & 0.0984 & & 0.2821 & & 0.3296 & \\
\hline & $(0.030)$ & ** & $(0.034)$ & $* *$ & $(0.034)$ & $* *$ & $(0.034)$ & * & $(0.049)$ & ** & $(0.044)$ & $* *$ \\
\hline \multirow[t]{2}{*}{ UK } & 0.6123 & & 0.5245 & & 0.4947 & & 0.0584 & & 0.0104 & & 0.0419 & \\
\hline & $(0.027)$ & ** & $(0.024)$ & $* *$ & $(0.027)$ & ** & $(0.027)$ & ** & $(0.032)$ & & $(0.033)$ & \\
\hline \multirow[t]{2}{*}{ Germany } & 0.2516 & & 0.7708 & & 0.7154 & & 0.7594 & & 1.433 & & 1.2091 & \\
\hline & $(0.028)$ & ** & $(0.031)$ & ** & $(0.032)$ & ** & $(0.028)$ & ** & $(0.042)$ & ** & $(0.040)$ & ** \\
\hline \multirow[t]{2}{*}{ France } & 0.3295 & & 0.2912 & & 0.212 & & 0.2246 & & -0.045 & & -0.0488 & \\
\hline & $(0.027)$ & ** & $(0.025)$ & ** & $(0.030)$ & ** & $(0.024)$ & ** & $(0.030)$ & & $(0.035)$ & \\
\hline \multirow[t]{2}{*}{ US } & 0.131 & & 0.238 & & 0.177 & & 0.2659 & & 0.2284 & & 0.1851 & \\
\hline & $(0.022)$ & $* *$ & $(0.023)$ & $*$ & $(0.021)$ & $* *$ & $(0.025)$ & ** & $(0.033)$ & $* *$ & $(0.028)$ & $* *$ \\
\hline
\end{tabular}


Table 2. Accumulated Impulse Responses in Alternative Orders (continued)

\begin{tabular}{|c|c|c|c|c|c|c|c|c|c|c|c|c|}
\hline & (3) France & & & & & & (4) US & & & & & \\
\hline & $1992-1996$ & & $2000-2006$ & & $2010-2016$ & & 1992-1996 & & $2000-2006$ & & $2010-2016$ & \\
\hline \multirow[t]{2}{*}{ China } & 0.0757 & & -0.0541 & & -0.0154 & & -0.0136 & & 0.0287 & & 0.0166 & \\
\hline & $(0.042)$ & & $(0.046)$ & & $(0.046)$ & & $(0.026)$ & & $(0.035)$ & & $(0.031)$ & \\
\hline \multirow[t]{2}{*}{ Hong Kong } & 0.0837 & & 0.1314 & & 0.2072 & & 0.0106 & & -0.0156 & & 0.0635 & \\
\hline & $(0.040)$ & $*$ & $(0.045)$ & * & $(0.043)$ & ** & $(0.025)$ & & $(0.034)$ & & $(0.028)$ & * \\
\hline \multirow[t]{2}{*}{ Korea } & -0.0058 & & 0.1717 & & 0.2722 & & 0.0126 & & 0.0796 & & 0.1617 & \\
\hline & $(0.041)$ & & $(0.045)$ & $* *$ & $(0.046)$ & ** & $(0.026)$ & & $(0.034)$ & $*$ & $(0.030)$ & $* *$ \\
\hline \multirow[t]{2}{*}{ Singapore } & 0.0827 & & 0.2242 & & 0.4091 & & 0.0438 & & 0.0767 & & 0.222 & \\
\hline & $(0.043)$ & & $(0.044)$ & ** & $(0.044)$ & ** & $(0.027)$ & & $(0.034)$ & $*$ & $(0.029)$ & $* *$ \\
\hline \multirow[t]{2}{*}{ Taiwan } & 0.0222 & & 0.0692 & & 0.0583 & & -0.0304 & & 0.0702 & & 0.0571 & \\
\hline & $(0.040)$ & & $(0.044)$ & & $(0.044)$ & & $(0.025)$ & & $(0.034)$ & * & $(0.029)$ & \\
\hline \multirow[t]{2}{*}{ Thailand } & -0.0268 & & 0.0432 & & 0.0234 & & -0.0205 & & -0.0212 & & -0.00648 & \\
\hline & $(0.042)$ & & $(0.044)$ & & $(0.044)$ & & $(0.026)$ & & $(0.034)$ & & $(0.029)$ & \\
\hline \multirow[t]{2}{*}{ Malaysia } & -0.0198 & & -0.2011 & & -0.0175 & & 0.00735 & & -0.1185 & & -0.0376 & \\
\hline & $(0.042)$ & & $(0.050)$ & $* *$ & $(0.046)$ & & $(0.026)$ & & $(0.038)$ & $*$ & $(0.031)$ & \\
\hline \multirow[t]{2}{*}{ Indonesia } & 0.0363 & & -0.0895 & & 0.0431 & & 0.0199 & & -0.0596 & & 0.0239 & \\
\hline & $(0.046)$ & & $(0.047)$ & & $(0.045)$ & & $(0.029)$ & & $(0.036)$ & & $(0.030)$ & \\
\hline \multirow[t]{2}{*}{ Phillipines } & -0.0015 & & -0.0375 & & -0.1224 & & -0.000992 & & 0.00894 & & -0.0436 & \\
\hline & $(0.043)$ & & $(0.046)$ & & $(0.044)$ & $*$ & $(0.027)$ & & $(0.036)$ & & $(0.029)$ & \\
\hline \multirow[t]{2}{*}{ Japan } & 0.1472 & & 0.2368 & & 0.3397 & & 0.0525 & & 0.1044 & & 0.1945 & \\
\hline & $(0.041)$ & $* *$ & $(0.044)$ & $* *$ & $(0.044)$ & ** & $(0.025)$ & * & $(0.033)$ & ** & $(0.029)$ & $* *$ \\
\hline \multirow[t]{2}{*}{ UK } & -0.00271 & & 0.0025 & & 0.0609 & & 0.0998 & & 0.056 & & 0.1758 & \\
\hline & $(0.032)$ & & $(0.029)$ & & $(0.033)$ & & $(0.026)$ & ** & $(0.029)$ & & $(0.026)$ & ** \\
\hline \multirow[t]{2}{*}{ Germany } & 0.4333 & & 1.1493 & & 1.1125 & & 0.0706 & & 0.5973 & & 0.5416 & \\
\hline & $(0.038)$ & ** & $(0.039)$ & $* *$ & $(0.041)$ & ** & $(0.024)$ & * & $(0.032)$ & ** & $(0.028)$ & ** \\
\hline \multirow[t]{2}{*}{ France } & 0.9075 & & 0.5387 & & 0.4469 & & 0.1716 & & -0.0288 & & 0.1131 & \\
\hline & $(0.033)$ & ** & $(0.028)$ & $* *$ & $(0.036)$ & ** & $(0.024)$ & ** & $(0.028)$ & & $(0.027)$ & ** \\
\hline \multirow[t]{2}{*}{ US } & 0.1903 & & 0.2676 & & 0.1943 & & 0.6075 & & 0.8287 & & 0.5828 & \\
\hline & $(0.030)$ & $* *$ & $(0.030)$ & $* *$ & $(0.028)$ & ** & $(0.022)$ & ** & $(0.026)$ & ** & $(0.021)$ & $* *$ \\
\hline
\end{tabular}

Note 1) Table reports accumulated impulse responses over 10 business days after a shock.

2) Standard error is in the parenthesis.

$3)^{*}$ means that $\pm 2 \sigma$ is different from zero. ** means that $\pm 3 \sigma$ is different from zero. 
Table 3. The Effects of Manufacturing and Financial Sectors

(1) UK

\begin{tabular}{|c|c|c|c|c|c|c|c|c|c|c|c|}
\hline & \multicolumn{4}{|c|}{ Manufacturing Sector } & \multirow[b]{2}{*}{$2010-2016$} & & \multicolumn{3}{|c|}{ Financial Sector } & \multirow[b]{2}{*}{$2010-2016$} & \\
\hline & 1993-1996 & & $2000-2006$ & & & & 1993-1996 & & $2000-2006$ & & \\
\hline \multirow[t]{2}{*}{ China } & -0.018 & & 0.0112 & & 0.2729 & & 0.0278 & & \begin{tabular}{|l}
0.0077 \\
\end{tabular} & 0.1386 & \\
\hline & $(0.049)$ & & $(0.041)$ & & $(0.042)$ & ** & $(0.049)$ & & $(0.041)$ & $(0.040)$ & ** \\
\hline \multirow[t]{2}{*}{ Hong Kong } & 0.1732 & & 0.181 & & 0.125 & & 0.1460 & & 0.0470 & 0.0428 & \\
\hline & $(0.049)$ & ** & $(0.042)$ & ** & $(0.040)$ & ** & $(0.048)$ & $*$ & $(0.043)$ & $(0.040)$ & \\
\hline \multirow[t]{2}{*}{ Korea } & 0.0886 & & $4.84 \mathrm{E}-03$ & & 0.0841 & & 0.0192 & & -0.030 & -0.0216 & \\
\hline & $(0.049)$ & & $(0.040)$ & & $(0.038)$ & * & $(0.045)$ & & $(0.043)$ & $(0.039)$ & \\
\hline \multirow[t]{2}{*}{ Singapore } & 0.1337 & & 0.1303 & & 0.1832 & & 0.0257 & & 0.0170 & 0.1173 & \\
\hline & $(0.046)$ & * & $(0.040)$ & ** & $(0.038)$ & ** & $(0.044)$ & & $(0.040)$ & $(0.039)$ & * \\
\hline \multirow[t]{2}{*}{ Taiwan } & 0.0288 & & 0.0327 & & 0.0366 & & 0.0275 & & -0.0026 & -0.0469 & \\
\hline & $(0.047)$ & & $(0.042)$ & & $(0.038)$ & & $(0.051)$ & & $(0.044)$ & $(0.041)$ & \\
\hline \multirow[t]{2}{*}{ Thailand } & -0.1036 & & -0.0824 & & -0.0139 & & 0.087 & & 0.0238 & 0.0013 & \\
\hline & $(0.051)$ & $*$ & $(0.041)$ & * & $(0.038)$ & & $(0.040) *$ & & $(0.039)$ & $(0.034)$ & \\
\hline
\end{tabular}

(2) Germany

\begin{tabular}{|c|c|c|c|c|c|c|c|c|c|c|}
\hline & \multicolumn{4}{|c|}{ Manufacturing Sector } & \multirow[b]{2}{*}{$2010-2016$} & & \multicolumn{2}{|c|}{ Financial Sector } & \multirow[b]{2}{*}{$2010-2016$} & \\
\hline & $1993-1996$ & & $2000-2006$ & & & & $1993-1996$ & $2000-2006$ & & \\
\hline \multirow[t]{2}{*}{ China } & -0.0016 & & 0.0398 & & 0.2993 & & 0.0061 & 0.0228 & 0.1534 & \\
\hline & $(0.053)$ & & $(0.063)$ & & $(0.055)$ & ** & $(0.053)$ & $(0.063)$ & $(0.053)$ & ** \\
\hline \multirow[t]{2}{*}{ Hong Kong } & 0.1853 & & 0.3757 & & 0.1664 & & 0.0983 & -0.0321 & 0.0078 & \\
\hline & $(0.053)$ & ** & $(0.063)$ & ** & $(0.052)$ & ** & $(0.052)$ & $(0.064)$ & $(0.052)$ & \\
\hline \multirow[t]{2}{*}{ Korea } & 0.0306 & & 0.0336 & & 0.0695 & & 0.0242 & 0.0118 & -0.0678 & \\
\hline & $(0.053)$ & & $(0.060)$ & & $(0.051)$ & & $(0.050)$ & $(0.065)$ & $(0.052)$ & \\
\hline \multirow[t]{2}{*}{ Singapore } & 0.1154 & & 0.2151 & & 0.2419 & & -0.034 & -0.0120 & 0.1451 & \\
\hline & $(0.051)$ & $*$ & $(0.061)$ & ** & $(0.050)$ & ** & $(0.049)$ & $(0.061)$ & $(0.052)$ & $*$ \\
\hline \multirow[t]{2}{*}{ Taiwan } & 0.0296 & & 0.0758 & & 0.0298 & & 0.0126 & 0.0258 & -0.0529 & \\
\hline & $(0.052)$ & & $(0.063)$ & & $(0.050)$ & & $(0.056)$ & $(0.067)$ & $(0.053)$ & \\
\hline \multirow[t]{2}{*}{ Thailand } & 0.0259 & & -0.0585 & & 0.0054 & & 0.0220 & 0.0724 & 0.0359 & \\
\hline & $(0.056)$ & & $(0.062)$ & & $(0.050)$ & & $(0.045)$ & $(0.058)$ & $(0.045)$ & \\
\hline
\end{tabular}


Table 3. The Effects of Manufacturing and Financial Sectors (continued)

(3) France

\begin{tabular}{|c|c|c|c|c|c|c|c|c|c|c|c|}
\hline & \multicolumn{3}{|c|}{ Manufacturing Sector } & & & & \multicolumn{3}{|c|}{ Financial Sector } & \multirow[b]{2}{*}{$2010-2016$} & \\
\hline & 1993-1996 & & 2000-2006 & & $2010-2016$ & & 1993-1996 & & 2000-2006 & & \\
\hline \multirow[t]{2}{*}{ China } & -0.1036 & & 0.0322 & & 0.3450 & & -0.0403 & & -0.0325 & 0.1605 & \\
\hline & $(0.069)$ & & $(0.056)$ & & $(0.055)$ & $* *$ & $(0.069)$ & & $(0.056)$ & $(0.052)$ & ** \\
\hline \multirow[t]{2}{*}{ Hong Kong } & 0.1316 & & 0.3049 & & 0.1486 & & 0.1433 & & -0.0038 & 0.0084 & \\
\hline & $(0.069)$ & & $(0.056)$ & $* *$ & $(0.052)$ & * & $(0.068)$ & $*$ & $(0.057)$ & $(0.052)$ & \\
\hline \multirow[t]{2}{*}{ Korea } & 0.1260 & & 0.0138 & & 0.0576 & & 0.0075 & & -0.0522 & -0.0195 & \\
\hline & $(0.070)$ & & $(0.053)$ & & $(0.050)$ & & $(0.065)$ & & $(0.057)$ & $(0.051)$ & \\
\hline \multirow[t]{2}{*}{ Singapore } & 0.1558 & & 0.1676 & & 0.2398 & & -0.0358 & & 0.0352 & 0.1444 & \\
\hline & $(0.066)$ & * & $(0.054)$ & ** & $(0.050)$ & $* *$ & $(0.064)$ & & $(0.054)$ & $(0.052)$ & $*$ \\
\hline \multirow[t]{2}{*}{ Taiwan } & 0.0173 & & 0.0285 & & 0.0194 & & 0.0036 & & 0.0331 & -0.0609 & \\
\hline & $(0.068)$ & & $(0.055)$ & & $(0.050)$ & & $(0.072)$ & & $(0.059)$ & $(0.053)$ & \\
\hline \multirow[t]{2}{*}{ Thailand } & 0.0029 & & -0.0789 & & -0.0282 & & -0.0571 & & 0.0853 & 0.0134 & \\
\hline & $(0.073)$ & & $(0.055)$ & & $(0.050)$ & & $(0.058)$ & & $(0.051)$ & $(0.044)$ & \\
\hline
\end{tabular}

(4) USA

\begin{tabular}{|c|c|c|c|c|c|c|c|c|c|c|}
\hline & \multicolumn{3}{|c|}{ Manufacturing Sector } & & & & \multicolumn{2}{|c|}{ Financial Sector } & \multirow[b]{2}{*}{ 2010-2016 } & \\
\hline & 1993-1996 & & $2000-2006$ & & $2010-2016$ & & 1993-1996 & $2000-2006$ & & \\
\hline \multirow[t]{2}{*}{ China } & -0.0613 & & 0.0240 & & 0.1756 & & -0.0577 & 0.0406 & 0.0888 & \\
\hline & $(0.053)$ & & $(0.042)$ & & $(0.037)$ & ** & $(0.053)$ & $(0.042)$ & $(0.036)$ & * \\
\hline \multirow[t]{2}{*}{ Hong Kong } & 0.037 & & 0.1062 & & 0.0857 & & 0.0602 & 0.0104 & -0.0084 & \\
\hline & $(0.053)$ & & $(0.042)$ & * & $(0.035)$ & * & $(0.052)$ & $(0.043)$ & $(0.035)$ & \\
\hline \multirow[t]{2}{*}{ Korea } & 0.0538 & & 0.0265 & & 0.0551 & & -0.0051 & -0.0677 & -0.0577 & \\
\hline & $(0.054)$ & & $(0.040)$ & & $(0.034)$ & & $(0.050)$ & $(0.043)$ & $(0.035)$ & \\
\hline \multirow[t]{2}{*}{ Singapore } & 0.1323 & & 0.0615 & & 0.1543 & & -0.0267 & 0.0714 & 0.0801 & \\
\hline & $(0.051)$ & * & $(0.041)$ & & $(0.034)$ & $* *$ & $(0.049)$ & $(0.041)$ & $(0.035)$ & * \\
\hline \multirow[t]{2}{*}{ Taiwan } & 0.0157 & & 0.0188 & & 0.0282 & & -0.0715 & 0.000409 & -0.0112 & \\
\hline & $(0.052)$ & & $(0.042)$ & & $(0.034)$ & & $(0.056)$ & $(0.045)$ & $(0.036)$ & \\
\hline \multirow[t]{2}{*}{ Thailand } & -0.074 & & -0.0577 & & -0.0318 & & 0.0045 & 0.0272 & -0.0205 & \\
\hline & $(0.056)$ & & $(0.041)$ & & $(0.034)$ & & $(0.045)$ & $(0.039)$ & $(0.030)$ & \\
\hline
\end{tabular}

Note 1) Table reports accumulated impulse responses over 10 business days after a shock.

2) Standard error is in the parenthesis.

$3) *$ means that $\pm 2 \sigma$ is different from zero. ** means that $\pm 3 \sigma$ is different from zero. 
Table 4. Accumulated Impulse Responses in the FX Markets

\begin{tabular}{|c|c|c|c|c|c|c|c|c|c|c|c|c|}
\hline & UK pound & & & & Euro & & & & US dollar & & & \\
\hline & $2000-2006$ & & $2010-2016$ & & $2000-2006$ & & $2010-2016$ & & $2000-2006$ & & $2010-2016$ & \\
\hline \multirow[t]{2}{*}{ China } & 0.1899 & $* *$ & 0.4715 & $* *$ & 0.0856 & ** & 0.3150 & $* *$ & 0.4757 & $* *$ & 0.5574 & ** \\
\hline & $(0.015)$ & & $(0.025)$ & & $(0.010)$ & & $(0.022)$ & & $(0.017)$ & & $(0.022)$ & \\
\hline \multirow[t]{2}{*}{ Hong Kong } & 0.0228 & & 0.0508 & $*$ & -0.0024 & & 0.0615 & * & 0.0574 & $* *$ & 0.1485 & $* *$ \\
\hline & $(0.013)$ & & $(0.025)$ & & $(0.009)$ & & $(0.022)$ & & $(0.011)$ & & $(0.021)$ & \\
\hline \multirow[t]{2}{*}{ Korea } & 0.0128 & & 0.172 & ** & -0.0037 & & 0.1504 & $* *$ & -0.0216 & & 0.0385 & $*$ \\
\hline & $(0.013)$ & & $(0.020)$ & & $(0.010)$ & & $(0.019)$ & & $(0.011)$ & & $(0.016)$ & \\
\hline \multirow[t]{2}{*}{ Singapore } & 0.0332 & * & 0.1928 & ** & 0.0359 & $* *$ & 0.1976 & $* *$ & -0.0188 & & 0.0023 & \\
\hline & $(0.014)$ & & $(0.022)$ & & $(0.010)$ & & $(0.020)$ & & $(0.013)$ & & $(0.018)$ & \\
\hline \multirow[t]{2}{*}{ Taiwan } & 0.0211 & & 0.0318 & & 0.0148 & & 0.0086 & & 0.0051 & & -0.0101 & \\
\hline & $(0.013)$ & & $(0.020)$ & & $(0.010)$ & & $(0.018)$ & & $(0.011)$ & & $(0.016)$ & \\
\hline \multirow[t]{2}{*}{ Thailand } & 0.016 & & 0.000631 & & 0.0056 & & 0.025 & & 0.0088 & & -0.0014 & \\
\hline & $(0.012)$ & & $(0.024)$ & & $(0.010)$ & & $(0.021)$ & & $(0.010)$ & & $(0.021)$ & \\
\hline \multirow[t]{2}{*}{ Malaysia } & 0.0087 & & -0.0262 & & 0.0040 & & -0.0473 & $*$ & 0.0070 & & -0.0104 & \\
\hline & $(0.012)$ & & $(0.020)$ & & $(0.010)$ & & $(0.018)$ & & $(0.010)$ & & $(0.016)$ & \\
\hline \multirow[t]{2}{*}{ Indonesia } & 0.0069 & & -0.0197 & & -0.0107 & & -0.0213 & & -0.0243 & & -0.0087 & \\
\hline & $(0.015)$ & & $(0.024)$ & & $(0.010)$ & & $(0.022)$ & & $(0.015)$ & & $(0.021)$ & \\
\hline \multirow[t]{2}{*}{ Phillipines } & -0.0241 & & 0.0003 & & -0.0124 & & 0.00951 & & 0.0022 & & 0.0029 & \\
\hline & $(0.014)$ & & $(0.021)$ & & $(0.010)$ & & $(0.019)$ & & $(0.013)$ & & $(0.017)$ & \\
\hline \multirow[t]{2}{*}{ Japan } & 0.2334 & ** & 0.4198 & ** & 0.0706 & ** & 0.3927 & ** & 0.4088 & ** & 0.5629 & $* *$ \\
\hline & $(0.016)$ & & $(0.028)$ & & $(0.010)$ & & $(0.024)$ & & $(0.020)$ & & $(0.027)$ & \\
\hline \multirow[t]{2}{*}{ UK } & 0.4000 & ** & 0.4592 & ** & 0.142 & ** & 0.180 & ** & 0.0092 & & -0.0308 & \\
\hline & $(0.013)$ & & $(0.021)$ & & $(0.010)$ & & $(0.020)$ & & $(0.014)$ & & $(0.019)$ & \\
\hline \multirow[t]{2}{*}{ EU } & -0.0595 & ** & -0.0172 & & 0.2470 & ** & 0.4082 & ** & -0.029 & ** & 0.0020 & \\
\hline & $(0.010)$ & & $(0.019)$ & & $(0.010)$ & & $(0.018)$ & & $(0.012)$ & & $(0.019)$ & \\
\hline \multirow[t]{2}{*}{ US } & -0.0029 & & -0.0242 & & -0.0104 & & -0.0116 & & 0.0346 & * & 0.0006 & \\
\hline & $(0.094)$ & & $(0.019)$ & & $(0.010)$ & & $(0.017)$ & & $(0.012)$ & & $(0.019)$ & \\
\hline
\end{tabular}

Note 1) Table reports accumulated impulse responses over 10 business days after a shock.

2) Standard error is in the parenthesis.

$3)$ * means that $\pm 2 \sigma$ is different from zero. ** means that $\pm 3 \sigma$ is different from zero. 
Table 5. Hourly Spillover Effects of the Exchange Rates

\begin{tabular}{|l|c|c|c|c|l|l|}
\cline { 2 - 7 } \multicolumn{1}{l|}{} & US Dollar & & UK Pound & Euro & \\
\hline Constant term & 0.001 & 0.001 & -0.002 & -0.002 & -0.002 & -0.002 \\
& $(0.001)$ & $(0.001)$ & $(0.001)^{* * *}$ & $(0.001)^{* * *}$ & $(0.001)^{* *}$ & $(0.001)^{* * *}$ \\
\hline Dependent var.(-1) & -0.047 & & -0.011 & & -0.075 & \\
& $(0.016)^{* * *}$ & & $(0.017)$ & & $(0.020)^{* * *}$ & \\
\hline CNY & 0.268 & 0.269 & 0.052 & 0.051 & 0.007 & 0.005 \\
& $(0.012)^{* * *}$ & $(0.012)^{* * *}$ & $(0.013)^{* * *}$ & $(0.013)^{* * *}$ & $(0.013)$ & $(0.013)$ \\
\hline USD & & & 0.415 & 0.416 & -0.013 & -0.003 \\
& & & $(0.021)^{* * *}$ & $(0.021)^{* * *}$ & $(0.023)$ & $(0.023)$ \\
\hline Euro & -0.006 & -0.004 & 0.467 & 0.468 & & \\
& $(0.027)$ & $(0.027)$ & $(0.023)^{* * *}$ & $(0.023)^{* * *}$ & & \\
\hline Pound & 0.454 & 0.456 & & & 0.441 & 0.437 \\
\hline Yen & $(0.023)^{* * *}$ & $(0.023)^{* * *}$ & & & $(0.021)^{* * *}$ & $(0.021)^{* * *}$ \\
& 0.082 & 0.083 & -0.033 & -0.033 & 0.007 & 0.009 \\
\hline Adjusted R-squared & $(0.010)^{* * *}$ & $(0.010)^{* * *}$ & $(0.010)^{* * *}$ & $(0.010)^{* * *}$ & $(0.009)$ & $(0.009)$ \\
\hline D.W. & 0.541 & 0.539 & 0.513 & 0.513 & 0.303 & 0.297 \\
\hline
\end{tabular}

\begin{tabular}{|l|c|c|c|c|}
\cline { 2 - 5 } \multicolumn{1}{c|}{} & \multicolumn{3}{l|}{ Norway Krone } & \multicolumn{2}{l|}{ Canadian Dollar } \\
\hline Constant term & 0.001 & 0.001 & 0.000 & 0.000 \\
& $(0.001)$ & $(0.001)$ & $(0.001)$ & $(0.001)$ \\
\hline Dependent var.(-1) & -0.019 & & -0.022 & \\
& $(0.016)$ & & $(0.016)$ & \\
\hline CNY & 0.029 & 0.027 & 0.062 & 0.061 \\
& $(0.014)^{* *}$ & $(0.014)^{*}$ & $(0.014)^{* * *}$ & $(0.014)^{* * *}$ \\
\hline USD & -0.032 & -0.030 & 0.271 & 0.274 \\
& $(0.025)$ & $(0.025)$ & $(0.024)^{* * *}$ & $(0.024)^{* * *}$ \\
Euro & 0.830 & 0.831 & 0.279 & 0.280 \\
& $(0.027)^{* * *}$ & $(0.027)^{* * *}$ & $(0.026)^{* * *}$ & $(0.026)^{* * *}$ \\
Pound & 0.218 & 0.217 & 0.450 & 0.449 \\
\hline Yen & $(0.026)^{* * *}$ & $(0.026)^{* * *}$ & $(0.025)^{* * *}$ & $(0.025)^{* * *}$ \\
& -0.074 & -0.074 & -0.039 & -0.038 \\
\hline Adjusted R-squared & 0.549 & 0.549 & 0.596 & 0.595 \\
D.W. & 1.960 & 1.959 & 1.995 & 1.996 \\
\hline
\end{tabular}

Note) $*=$ significant at $10 \%, * *=$ significant at $5 \%$, and $* * *=$ significant at $1 \%$. 